\title{
Mapping the Critical Intellectual Capital of IRD
}

\author{
Rodrigues, D.M., Da Silva, A. A., Delgado, J.U. \\ IInstitute of Radiation Protection and Dosimetry /National Nuclear Energy Commission, \\ 22780-160, Brazil, Rio de Janeiro, RJ, Brazil, \\ danielle@ird.gov.br
}

\begin{abstract}
Currently, several researches focus on the topic of Knowledge Management, mainly aimed at preserving and transferring intellectual capital, which promote the retention of critical knowledge in Institutions. The National Nuclear Energy Commission (CNEN) of Brazil, the federal authority responsible for the national nuclear energy standards, research, development, and regulation, has been facing difficulties in human resources due to the increase in the number of retirements and the lack of replacement of people, especially with the scientifictechnical profile, as a result of the cancelation of public employee hiring in the country. The purpose of this study is to map the critical technical areas at the Institute of Radiation Protection and Dosimetry (IRD), from CNEN. A model used by the International Atomic Energy Agency (IAEA) was adopted here, which takes into account the time for retirement, beyond the specificity and availability of knowledge. As a result of the study, it was possible to identify that in all end-areas, the IRD has employees that retain the critical knowledge, but they are hard to be replaced or transfer their knowledge. Therefore, a management plan should be implemented for the retention and transfer of knowledge specific to the nuclear area, which is essential for IRD to continue to meet its strategic objectives and that also contributes to minimize the impacts to the country generated by the loss of this sensitive and specialized knowledge. It was possible to identify that the areas that will be most affected by the loss of critical knowledge are radiation protection and metrology.
\end{abstract}

Key-Words: knowledge management, nuclear, critical knowledge 


\section{1- INTRODUCTION}

The National Nuclear Energy Commission of Brazil (CNEN) and its institutes are facing, over the years, the aging of the workforce and, consequently, a significant drain due to retirements. This fact, added to the lack of sufficient public tenders to meet the reduction of the number of employees, can cause a significant loss of institutional knowledge [1].

This work focused on the Institute of Radiation Protection and Dosimetry (IRD) in order to map the areas where the loss of knowledge can be classified as being critical to the continuity of the activities developed. This loss of critical knowledge is due to both the specificity of knowledge and the skills required performing the function, as well as the difficulty in recovering this kind of knowledge.

So, with regard to the IRD, the loss of intellectual capital generated by the growing number of retirements unleashes a huge damage to the area of radiation protection and dosimetry, once the technologies, experiences and knowledge gained from decades of research and development, are often not sufficiently documented, preserved and transferred.

Knowledge transfer involves two aspects as described [2]. First, it is the passage of knowledge to another person, while the second aspect refers to the assimilation of this knowledge by the person who is receiving. So, in order for the knowledge to be transferred effectively, it is necessary that both the transmitter and the receiver of knowledge be able to perform these two actions. However, several factors may prevent the knowledge to be transferred or stored. This paper focuses on mapping the critical areas threatened by the loss of intellectual capital, so that the mitigating and urgent actions may be directed to the most sensitive areas of IRD.

\section{2 - THE INSTITUTE OF RADIATION PROTECTION AND DOSIMETRY}

IRD is an institute of research, development and teaching in the area of radiation protection, dosimetry and metrology of ionizing radiation, linked to $\mathrm{CNEN}$, which operates in collaboration 
with universities, government agencies and industry to promote the safe use of ionizing radiation and nuclear technology.

The Institute represents one of the reference centers in Latin America with regard to the control of radioprotection, dosimetry and metrology of ionizing radiations. Among its many activities we can mention research in in the fields of radiological protection, dosimetry and metrology of ionizing radiation; keeping, developing and disseminating national standards; also participating and preparing trained and integrated personnel to respond at the national level to possible nuclear and radiological emergencies; providing specialized training and qualification of human resources to the nuclear sector and related; and others. [3]

IRD has four major areas of operation which are dosimetry, health physics, metrology and environmental radiation protection.

The dosimetry is the process that ensures the different practices with ionizing radiation are carried out in accordance with the norms established by CNEN with regards to the dose limit for occupationally exposed individuals. This area performs scientific research and technological development in physical, chemical, biological dosimetry, and mathematics, all with the goal of continuously improving the techniques employed. Specific tests are applied to external dosimetry exposures (when the irradiation source is external to the individual) and internal dosimetry (when of radioactive material in intake). There is also a provision of dosimetry services and consulting in the area of individual monitoring and managing national database of occupational doses to workers outside CNEN (management system of occupational doses).

The health physics refers to the application of ionizing radiation in medicine. This area of IRD develops scientific and technological research in radiodiagnostic, nuclear medicine and radiotherapy. Also develops studies on the biological effects on the environment resulting from the application of ionizing radiation in medical field. The medical physics research are also directed at the development and application of analytical and numerical mathematical methods for employment in radiation protection and dosimetry, improvement and application of methodologies of control and quality assurance radiodiagnostic, nuclear medicine and radiotherapy, as well as provides technical and scientific consulting in the field of medical physics.

Metrology is linked to the development, conservation and dissemination of national standards of the SI units for the quantities activity, fluency, Kerma, absorbed dose and dose equivalent, for 
various applications. There is provision of calibration services, supply of certified radiation standards and maintenance of standards and measurement systems for calibration of monitors, dosimeters and radioactive sources. The metrology area of IRD is also responsible for the custody and maintenance of the Brazilian standard in neutron fluency and responsible for the development of metrological techniques for the standardization of new radionuclides. It performs monitoring and continuous verification of the amount of radioactivity in samples of air, water, soil and food, which are of fundamental importance to maintain adequate levels of radiation safety.

Respect to the environmental radiation protection, this area aims to ensure the safe use of ionizing radiation in the country. The research in this area is dedicated to analysis for the determination of concentrations of radionuclides and stable elements in soils, plants, food, and minerals. There is also a strong performance in planning and executing actions of nuclear and radiological emergency response and environmental licensing processes. The laboratory contributes with technical and scientific cooperation, at national and international level, in the area of environmental and occupational radiation protection. The environmental radiation protection area is responsible, together with the metrology laboratory, of driving the national intercomparison analytical program of radionuclides in environmental samples. It is also responsible for the operation of the radionuclide air monitoring stations and to identify the presence of noble gases from nuclear explosions. The laboratory also provides analytical development and review of CNEN's radiation protection standards.

All of these major areas of the IRD cover the specific knowledge necessary for the continuity of the organization's activities.

Often the employee, that holds his own critical intellectual capital, does not identify and organize himself all the knowledge in order to transfer it to their successor or even leave recorded in documents way [4]. This kind of knowledge, identified as tacit knowledge, is intrinsic to an activity or process and, therefore, it becomes difficult to be captured and converted. Like most of the organizational knowledge is in the mind of the people who make up the staff of the organization, if the knowledge is critical for your performance, the person who holds it becomes essential, what makes your way out of a potential threat of loss of this resource [5].

Thus, the identification of critical intellectual knowledge is one of the main step to be considered in knowledge management. 


\section{3- METHODOLOGY: ASSESSING THE INTELLECTUAL CAPITAL OF IRD}

To map the critical knowledge of IRD, the model used by the IAEA (2006) was taken as the basis in which we considered: time for the employee's output, the knowledge, the ability of the employee and the availability of replacement staff, with similar knowledge and skill. This model is advantageous as it allows identifying immediately where there is the greatest risk of loss of critical knowledge.

First it is necessary to identify how many, of the total number of employee, already fulfilled the requirements for retirement, despite of carrying out normal activities. After, is important to know how many of these retiring employees have the critical knowledge for the accomplishment of the essential activities to achieve the mission of the IRD.

In this model, the so-called Dropout Risk and Position Risk Factors are taken into account. The Dropout Risk Factor is based on projection of time for the retirement of the employee, as described in Table 1[6]. The Position Risk Factor depends on the manager's analysis, taking into account the knowledge and unique skills possessed by employee, in addition to the estimation of the degree of difficulty or level of effort necessary to replenish the position, as shown in Table 2 [6]. So, by multiplying the Factors Dropout Risk by Position Risk, it is possible to reach the Total Risk Factor and their meanings (Table 3)[6].

Table 1 - Dropout.

\begin{tabular}{c|l}
\hline $\begin{array}{c}\text { Dropout } \\
\text { Risk } \\
\text { Factor }\end{array}$ & \\
\hline $\mathbf{5}$ & Estimated date of dropout between the current year or next year \\
\hline $\mathbf{4}$ & Estimated date of dropout in 3 years \\
\hline $\mathbf{3}$ & Estimated date of dropout in 4 years \\
\hline $\mathbf{2}$ & Estimated date of dropout in 5 years \\
\hline $\mathbf{1}$ & Estimated date of dropout in 6 or plus years \\
\hline
\end{tabular}


Table 2 - Position Risk Factor Criteria.

\begin{tabular}{c|l}
$\begin{array}{c}\text { Position } \\
\text { Risk } \\
\text { Factor }\end{array}$ & \multicolumn{1}{c}{ Criteria } \\
\hline $\mathbf{5}$ & $\begin{array}{l}\text { Knowledge or critical skills and uniques. Critical knowledge/skills to } \\
\text { the fulfillment of the institutional mission, with significant impact on } \\
\text { reliability or safety. Specific knowledge of the organization or } \\
\text { laboratory. Undocumented knowledge. It needs 3-5 years of training } \\
\text { and experience. There are not ready substitutes available. }\end{array}$ \\
\hline $\mathbf{4}$ & $\begin{array}{l}\text { Knowledge and critical skills. Critical knowledge/skills for } \\
\text { compliance with the institutional mission. Duplication of knowledge } \\
\text { exists to a limited extent in other laboratories or units and existence } \\
\text { of some documentation. Requires 2-4 years of training and } \\
\text { experience. }\end{array}$ \\
\hline $\mathbf{3}$ & $\begin{array}{l}\text { Important knowledge and skills and organized. There is } \\
\text { documentation and other staff on site that have the knowledge/skills. } \\
\text { Recruitment available. Can be trained in 1-2 years. }\end{array}$ \\
\hline $\mathbf{2}$ & $\begin{array}{l}\text { Knowledge and procedural skills or non-essential. There are } \\
\text { procedures. The training programs are available and effective, and } \\
\text { can be completed in less than 1 year. }\end{array}$ \\
\hline $\begin{array}{l}\text { Common knowledge and skills. External signings that have the } \\
\text { knowledge/skills are readily available and require little additional } \\
\text { training. }\end{array}$ \\
\hline
\end{tabular}

Table 3: Total Risk Factor.

\begin{tabular}{c|l}
\hline 20-25 & $\begin{array}{l}\text { High Priority - immediate action required. Plans of action for } \\
\text { specific substitutes replacement, with dates, must be developed to } \\
\text { include: Knowledge retention plan, evaluation of knowledge } \\
\text { management, specific training on the job. Training/shading of } \\
\text { historical incumbents. }\end{array}$ \\
\hline $\mathbf{1 6 - 1 9}$ & $\begin{array}{l}\text { Priority - replacement plans should be established to address the } \\
\text { method and substitution Time; recruitment efforts should be } \\
\text { established, training and shadowing of the current holder. }\end{array}$ \\
\hline $\mathbf{1 0 - 1 5}$ & $\begin{array}{l}\text { High important - taking into account the way in which the position } \\
\text { will be filled and the work done. University recruitment, training, } \\
\text { process improvements, reinvestment. }\end{array}$ \\
\hline $\mathbf{1 - 9}$ & $\begin{array}{l}\text { Important - recognition of roles and positions and identifying the } \\
\text { need for replacement. }\end{array}$ \\
\hline
\end{tabular}




\section{4- RESULTS AND DISCUSSION}

In IRD, we conducted the survey of employees that have fulfilled the prerequisites for retirement, but that by personal choice are still working. Thus, it was possible to identify that, at the time of this study, 46 employees holding the top-level position can submit the application for retirement at any time because they already have the conditions to do so. So, for these 46 employees, the score 5 was assigned to the Dropout Risk Factor. In parallel, the Director of the IRD, based on Table 2, attributed the score to the Position Risk Factor for each of these employees.

Taking into account the information contained in the database of human resources in 2017, the Institute currently has 108 top-level carreer, being 28 analysts, 26 researchers and 54 technologists. Of this total, 46 have already achieved the prerequisites for retirement, and are still working for personal choice. Transforming these values in percentages, we find that $43 \%$ of the current top-level effective may retire at any time as shown in the Figure 1 (RHFácil-CNEN).

Figure 1: Current situation of top-level employees at IRD.

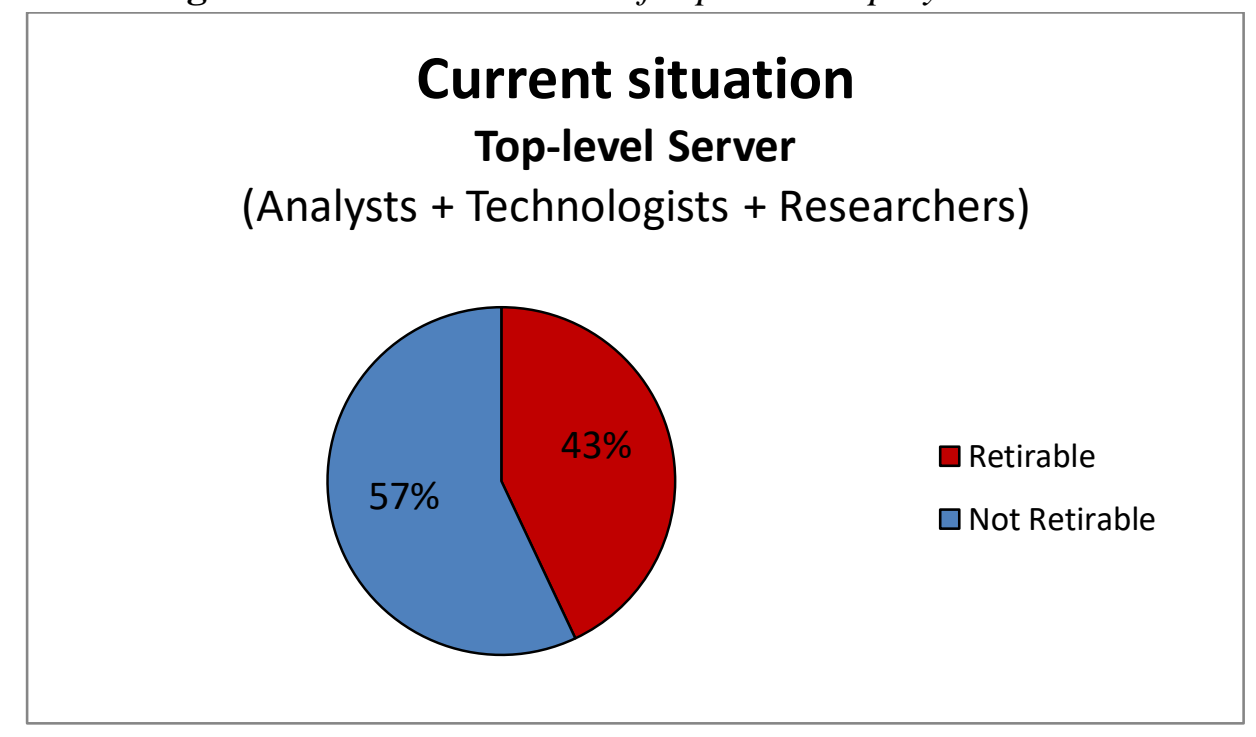


Considering the fact that critical knowledge is within the most important activities within the organization, we will focus on the finalistic areas, which include the careers of technologists and researchers.

Regarding the final area of the IRD, namely, technologists and researchers, there is an imminent risk of the loss of $40 \%$ of highly qualified personnel, as shown in figure 2.

Figure 2: Imminent risk of the loss highly qualified personnel

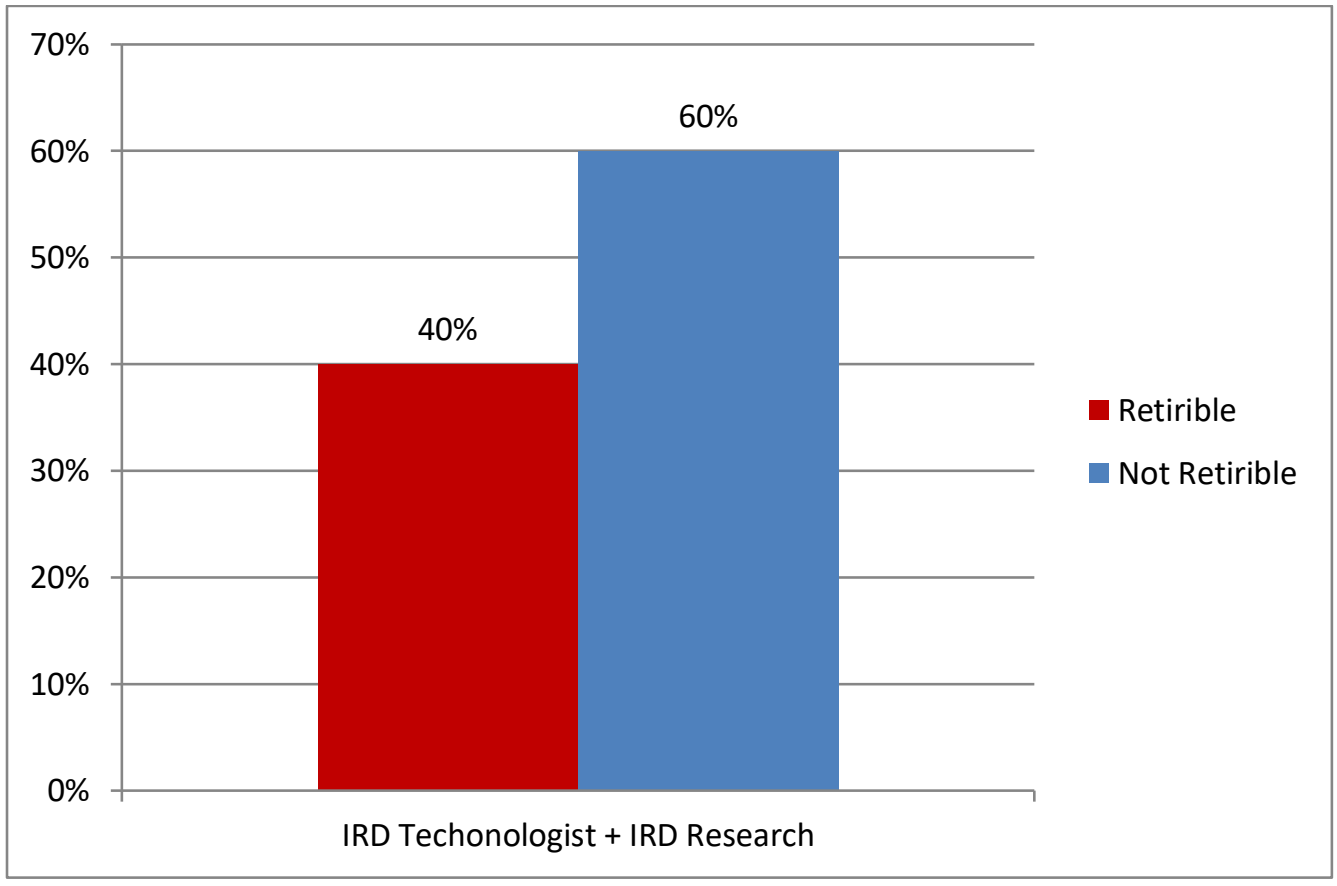

Table 4 shows the result corresponding to the total IRD risk factors, after applying the methodology adopted. 
Table 4: IRD Total Risk Factor.

\begin{tabular}{|c|c|c|c|c|c|}
\hline $\begin{array}{l}\text { RETIRIBLE } \\
\text { SERVER }\end{array}$ & AREA & $\begin{array}{l}\text { ATTRITION } \\
\text { FACTOR }\end{array}$ & $\begin{array}{c}\text { POSITION } \\
\text { RISK } \\
\text { FACTOR } \\
\end{array}$ & $\begin{array}{c}\text { TOTAL } \\
\text { RISK } \\
\text { FACTOR } \\
\end{array}$ & PRIORITY \\
\hline 1 & $\begin{array}{l}\text { Radiation } \\
\text { Protection }\end{array}$ & 5 & 5 & 25 & High Priority \\
\hline 2 & Metrology & 5 & 2 & 10 & $\begin{array}{c}\text { High } \\
\text { Importance }\end{array}$ \\
\hline 3 & Management & 5 & 3 & 15 & $\begin{array}{c}\text { High } \\
\text { Importance }\end{array}$ \\
\hline 4 & $\begin{array}{l}\text { Radiation } \\
\text { Protection }\end{array}$ & 5 & 4 & 20 & High Priority \\
\hline 5 & Metrology & 5 & 5 & 25 & High Priority \\
\hline 6 & $\begin{array}{l}\text { Education } \\
\text { and Training }\end{array}$ & 5 & 1 & 5 & Importante \\
\hline 7 & $\begin{array}{c}\text { Education } \\
\text { and Training }\end{array}$ & 5 & 4 & 20 & High Priority \\
\hline 8 & $\begin{array}{l}\text { Healthy } \\
\text { Physics }\end{array}$ & 5 & 2 & 10 & $\begin{array}{c}\text { High } \\
\text { Importance }\end{array}$ \\
\hline 9 & Metrology & 5 & 5 & 25 & High Priority \\
\hline 10 & $\begin{array}{l}\text { Healthy } \\
\text { Physics }\end{array}$ & 5 & 2 & 10 & $\begin{array}{c}\text { High } \\
\text { Importance }\end{array}$ \\
\hline 11 & $\begin{array}{l}\text { Radiation } \\
\text { Protection }\end{array}$ & 5 & 3 & 15 & $\begin{array}{c}\text { High } \\
\text { Importance }\end{array}$ \\
\hline 12 & Dosimetria & 5 & 5 & 25 & $\begin{array}{c}\text { High } \\
\text { Priority }\end{array}$ \\
\hline 13 & $\begin{array}{l}\text { Radiation } \\
\text { Protection } \\
\end{array}$ & 5 & 4 & 20 & $\begin{array}{l}\text { High } \\
\text { Priority }\end{array}$ \\
\hline 14 & Dosimetry & 5 & 3 & 15 & $\begin{array}{c}\text { High } \\
\text { Importance }\end{array}$ \\
\hline 15 & Metrology & 5 & 4 & 20 & $\begin{array}{c}\text { High } \\
\text { Priority }\end{array}$ \\
\hline 16 & $\begin{array}{l}\text { Radiation } \\
\text { Protection }\end{array}$ & 5 & 4 & 20 & $\begin{array}{l}\text { High } \\
\text { Priority }\end{array}$ \\
\hline 17 & Management & 5 & 3 & 15 & $\begin{array}{c}\text { High } \\
\text { Importance }\end{array}$ \\
\hline 18 & Management & 5 & 2 & 10 & $\begin{array}{c}\text { High } \\
\text { Importance }\end{array}$ \\
\hline 19 & Management & 5 & 3 & 15 & $\begin{array}{c}\text { High } \\
\text { Importance }\end{array}$ \\
\hline 20 & $\begin{array}{l}\text { Radiation } \\
\text { Protection }\end{array}$ & 5 & 4 & 20 & $\begin{array}{c}\text { High } \\
\text { Priority }\end{array}$ \\
\hline 21 & Metrology & 5 & 4 & 20 & $\begin{array}{c}\text { High } \\
\text { Priority }\end{array}$ \\
\hline 22 & Management & 5 & 3 & 15 & $\begin{array}{c}\text { High } \\
\text { Importance }\end{array}$ \\
\hline 23 & Management & 5 & 2 & 10 & High \\
\hline
\end{tabular}




\begin{tabular}{|c|c|c|c|c|c|}
\hline & & & & & Importance \\
\hline 24 & $\begin{array}{l}\text { Healthy } \\
\text { Physics }\end{array}$ & 5 & 2 & 10 & $\begin{array}{c}\text { High } \\
\text { Importance }\end{array}$ \\
\hline 25 & $\begin{array}{l}\text { Radiation } \\
\text { Protection }\end{array}$ & 5 & 5 & 25 & $\begin{array}{c}\text { High } \\
\text { Priority } \\
\end{array}$ \\
\hline 26 & Dosimetry & 5 & 5 & 25 & $\begin{array}{c}\text { High } \\
\text { Priority }\end{array}$ \\
\hline 27 & $\begin{array}{l}\text { Radiation } \\
\text { Protection }\end{array}$ & 5 & 4 & 20 & $\begin{array}{c}\text { High } \\
\text { Priority }\end{array}$ \\
\hline 28 & $\begin{array}{l}\text { Radiation } \\
\text { Protection }\end{array}$ & 5 & 5 & 25 & $\begin{array}{l}\text { High } \\
\text { Priority }\end{array}$ \\
\hline 29 & Management & 5 & 2 & 10 & $\begin{array}{c}\text { High } \\
\text { Importance }\end{array}$ \\
\hline 30 & $\begin{array}{l}\text { Healthy } \\
\text { Physics }\end{array}$ & 5 & 5 & 25 & $\begin{array}{c}\text { High } \\
\text { Priority } \\
\end{array}$ \\
\hline 31 & Management & 5 & 3 & 15 & $\begin{array}{c}\text { High } \\
\text { Importance }\end{array}$ \\
\hline 32 & $\begin{array}{l}\text { Radiation } \\
\text { Protection } \\
\end{array}$ & 5 & 5 & 25 & $\begin{array}{c}\text { High } \\
\text { Priority } \\
\end{array}$ \\
\hline 33 & Management & 5 & 3 & 15 & $\begin{array}{c}\text { High } \\
\text { Importance }\end{array}$ \\
\hline 34 & Management & 5 & 3 & 15 & $\begin{array}{c}\text { High } \\
\text { Importance }\end{array}$ \\
\hline 35 & $\begin{array}{l}\text { Radiation } \\
\text { Protection } \\
\end{array}$ & 5 & 3 & 15 & $\begin{array}{c}\text { High } \\
\text { Importance }\end{array}$ \\
\hline 36 & Management & 5 & 2 & 10 & $\begin{array}{c}\text { High } \\
\text { Importance } \\
\end{array}$ \\
\hline 37 & Dosimetry & 5 & 3 & 15 & $\begin{array}{c}\text { High } \\
\text { Importance }\end{array}$ \\
\hline 38 & Management & 5 & 2 & 10 & $\begin{array}{c}\text { High } \\
\text { Importance }\end{array}$ \\
\hline 39 & Management & 5 & 3 & 15 & $\begin{array}{c}\text { High } \\
\text { Importance } \\
\end{array}$ \\
\hline 40 & Metrology & 5 & 5 & 25 & $\begin{array}{c}\text { High } \\
\text { Priority } \\
\end{array}$ \\
\hline 41 & Management & 5 & 2 & 10 & $\begin{array}{c}\text { High } \\
\text { Importance }\end{array}$ \\
\hline 42 & Management & 5 & 2 & 10 & $\begin{array}{c}\text { High } \\
\text { Importance } \\
\end{array}$ \\
\hline 43 & Management & 5 & 3 & 15 & $\begin{array}{c}\text { High } \\
\text { Importance }\end{array}$ \\
\hline 44 & $\begin{array}{l}\text { Radiation } \\
\text { Protection }\end{array}$ & 5 & 3 & 15 & $\begin{array}{c}\text { High } \\
\text { Importance }\end{array}$ \\
\hline 45 & $\begin{array}{l}\text { Radiation } \\
\text { Protection }\end{array}$ & 5 & 3 & 15 & $\begin{array}{c}\text { High } \\
\text { Importance }\end{array}$ \\
\hline 46 & Metrology & 5 & 4 & 20 & $\begin{array}{c}\text { High } \\
\text { Priority } \\
\end{array}$ \\
\hline
\end{tabular}




\section{5- CONCLUSION}

In the nuclear sector, we often hear that only one person owns a particular kind of knowledge, but very little is done to prevent this problem. In a culture where knowledge is power, many fear losing their space, and so might not bother to transfer the knowledge acquired through years of work. On the other hand, we notice that there is a policy of encouragement for this to happen. This work pointed to the endangered areas with the greatest risks for loss of knowledge of the IRD.

It was possible to identify that, in all areas of IRD described, there are employees with highpriority risk factors.

The greatest risk of critical knowledge lost is radiation protection area, where nine IRD employees have an unique and hard skills to be replaced; followed by the metrology area, where there are six employees in this same situation.

A quick way of trying to preserve this intellectual capital should be proposed, in which filmed interviews are conducted with employees that are still working, but on the verge of retiring. At a more strategic level, actions should be developed to encourage a culture of knowledge transfer to future generations of employees.

For future research we suggest to extend the application of this methodology to other institutions of the nuclear sector that represent the risk of loss of intellectual capital, in order to mitigate the weakening of the area.

\section{REFERENCES}

[1] BRASIL, Emenda Constitucional no 95, Diário Oficial da União, Seção 1,16/12/2016, p.2, 2016.

[2] DAVENPORT, T.H. \& PRUSAK, L., "Conhecimento Empresarial: Como as organizações gerenciam o seu capital intelectual.” Elsevier, Rio de Janeiro, Brasil, 2003.

[3] BRASIL. Decreto n ${ }^{o}$ 8.886, Diário Oficial da União, Seção 1, 25/10/2016, p 8, 2016.

[4] MONTEIRO, C. A. "Estudo Sistêmico da Geração de Conhecimento no IPEN". Tese de Doutorado, IPEN/USP. São Paulo, 2016. 
[5] ACAR, M.E.D., "Modelagem sociotécnica de uma organização nuclear: estudo de caso aplicado ao laboratório Nacional de Metrologia das Radiações Ionizantes." Tese de Doutorado. IPEN/USP, São Paulo, Brasil, 2015.

[6] IAEA - International Atomic Energy Agency, "Risk Management of Knowledge Loss in Nuclear Industry Organization”. STI/PUB/1248, 2006. 